\title{
Lithuanian intensive causatives and their history
}

\author{
Axel Holvoet \\ Vilnius University
}

The article deals with a small group of Lithuanian verbs in which causative morphology has acquired an intensive function. While causative-intensive polyfunctionality is well attested typologically, the Lithuanian instance is interesting in that the intensive function manifests itself in reflexivised causatives. This development seems to be a consequence of the co-occurrence of causative and reflexive derivation as devices for building transitivity pairs in Baltic. The combination of the two devices yields intransitivised causatives that become semantically differentiated from the corresponding primary intransitives through developing an intensive function.

Keywords: causative, reflexive, intensive, Lithuanian, Baltic

\section{Introduction: the case of nešdintis ${ }^{1}$}

The non-causative functions of morphological markers with a primarily causative function are a well-established topic in the typological literature, starting with such classical publications as Nedjalkov \& Sil'nickij (1969, 35-38); for newer studies see Kittilä (2009) and Aikhenvald (2018). For Baltic there is a study on extended uses of causative morphology in Latvian (Holvoet 2015), but it is far from exhausting the subject. The present article deals with what appears to be an 'intensive' extension of causative marking in a small group of verbs in Lithuanian. The phenomenon we will be discussing is of interest because of its interactions with other categories, such as reflexivity and mood. Our discussion will start

\footnotetext{
${ }^{1}$ I wish to thank Rolandas Mikulskas, Peter Arkadiev, Wayles Browne and two external reviewers for their constructive comments, which have led to substantial improvements in my text. For all remaining shortcomings of the article I remain solely responsible. This research has received funding from the European Social Fund (project No. 09.3·3-LMT-K-712-01-0071) under grant agreement with the Research Council of Lithuania (LMTLT).
} 
out from an idiosyncratic case, that of the verb nešdintis 'get away, take oneself off':

(1) Lithuanian (Petras Dirgèla, 1994, CCLL)

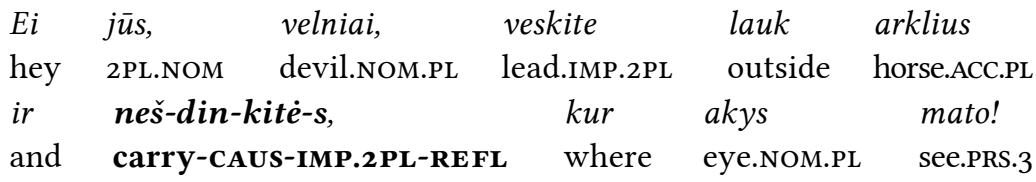

'Hey you, devils, lead the horses out and take yourselves off where your eyes carry you.'

The meaning of nešdintis is defined in LKž as 'nieko nelaukiant eiti, bègti, pasitraukti, sprukti' ('go, run, withdraw, escape without delay'). The verb is derived, with the causative suffix -din-, from the transitive nešti 'carry', and it moreover contains a reflexive marker. Assuming the derivational meaning to be compositional, and the causative and reflexive markers to have properly causative and reflexive functions respectively, ${ }^{2}$ we would expect either a meaning of the type 'cause (force) oneself to carry something or somebody (somewhere)' (coreferentiality of causer and causee-A), or one of the type 'have oneself carried (somewhere)' (coreferentiality of causer and $\mathrm{p}$ ). ${ }^{3}$ Actually the verb is intransitive, and its meaning involves only the subject's own motor control, so that there is no co-occurrence of causer and causee characteristic of causative constructions. Instead of this causative formation one would rather have expected a reflexive form of $n e s ̌ t i$, which is in itself a caused-motion verb, and indeed this is attested from the early zoth century, though apparently no longer used nowadays: ${ }^{4}$

(2) Lithuanian (Draugas, 10-10-1912)

[feigu nenori prigulet $i$ vietinès kuopos unija, ]

$\begin{array}{llll}\text { tai } & \text { kuo greičiau } & \text { neški-s } & i s ̌ \\ \text { then } & \text { as.quickly.as.possible } & \text { carry.IMP.2SG-REFL } & \text { from }\end{array}$

\footnotetext{
${ }^{2}$ In the case of the reflexive marker it is by no means obvious that the function should be properly reflexive, as the affixal reflexive marker has mainly middle-voice rather than reflexive functions, cf. Holvoet (2020). The assumption of a properly reflexive function is here made for purposes of exposition.

${ }^{3}$ A reviewer suggests a kind of reflexive haplology could also be involved, i.e., nešdinkitess could be thought of as a reflexive relating to both the causee and the patient: 'make oneself carry oneself'. Though this is conceivable, there would be no parallel for it in Baltic.

${ }^{4}$ To be more precise, neštis is frequently used but as a transitive verb meaning 'carry with one, carry along': neškis savo daiktus 'take your belongings with you'.
} 
to miestelio, ...

that.GEN.SG town.GEN.SG

'[If you don't want to belong to the local trade union,] then you'd better get out of that little town as quickly as possible. ${ }^{5}$

(3) Lithuanian (Keleivis, 11-12-1918)

[Tai tamsta socialistas!' - İsikiša tūlas individiumas, ${ }^{6}$ isiklausęs i mano klausinejima. - Taip! - atsakiau.]

Tai neški-s iš čia greičiau lauk,

then carry.IMP.2sG-REFL from here quickly out

[nes žydberniams čia vietos nèra.]

'["So you're a socialist, sir!", many an individual would interrupt me, having listened for a while to my questioning. "Yes", I answered.] "Then get out of here quickly, [because there's no place for Jews here."]'7

What, then, is the function of the causative suffix in nešdintis? From the dictionary definition, which emphasises the sudden character of the motion as well as an element of external compulsion suggested by the explicans 'escape', we might surmise that it could perhaps be intensive. Causativity-intensivity polysemy is reported from many languages. This notion of intensivity is usually viewed as a cluster of meanings, partly qualitative-pertaining to the internal structure of an event-and partly quantitative-iterative and distributive (Kulikov 2001, 894); here only the former are involved. Dixon (2000, 71-72) formulates differences associated with intensivity in causatives in terms of naturalness and effort, and this applies readily to the verb under discussion here: the naturalness applies to the usual psychomotor control, or to natural motion determined by the laws of physics, while conscious, directed effort or external pressure diverge from the natural. The instances of 'intensive' meaning of causative morphology mentioned in the literature are mostly instances of causatives derived from verbs that are already transitive ('second causatives', i.e. causatives derived from causatives, may be involved, see Kulikov 1993), and this applies, in a sense, to nešdintis, which derives from the transitive caused-motion verb nešti; true, the latter has no overt marking of its causative character. Two things are, however, unusual about nešdintis.

\footnotetext{
${ }^{5}$ http://www.draugas.org/archive/1912_reg/1912-10-10-DRAUGASw.pdf (accessed 10-07-2020)

${ }^{6}$ Sic!

${ }^{7}$ http://www.spauda.org/keleivis/archive/1918/1918-12-11-KELEIVIS.pdf (accessed 10-07-2020)
} 
First, its putative intensive meaning appears only in the reflexive form: the non-reflexive form shows-to the extent that it is still used-the structural causative meaning 'have somebody carry, bring something', on which below. Secondly, there appear to be no other verbs in Lithuanian showing exactly the same meaning and derivational pattern.

In this article we will attempt to explain the origin of the intensivecausative reflexive verb nešdintis, the interest of which lies in the fact that it sheds more light on a somewhat broader development within verbs combining causative and reflexive marking in Baltic.

\section{Other reflexive causatives in Lithuanian}

The exact derivational pattern represented by the verb nešdintis is, as mentioned above, not found in other Lithuanian verbs. We can, however, find verbs with similar causative marking and similar meaning, but with a different derivation. An example would be judintis in (4):

(4) Lithuanian (Aidas Pelenis, Keturiolika Restitucijos dienu, 1997, CCLL)

Tik sparčiau, judinki-s, only faster move.CAUS.IMP.2SG-REFL

[tu juk nemanai, kad aš čia liksiu laukti savo draugu...]

'Just hurry up, get moving, [or do you suppose I'm going to wait here for my friends...]'

As an imperative, this form judinkis is similar in function to nešdinkis: it is an appeal to quick and energetic action. In fact, 49 out of the 83 occurrences of the verb judintis attested in CCLL are imperatives. But the derivational history of the two verbs is different: whereas nešdintis derives from the transitive caused-motion verb nešti 'carry', judintis is the reflexive form of judinti, a causative derived from the intransitive motion verb judeti 'move'. Causative verbs are mostly derived from intransitive verbs in Baltic (see Arkadiev \& Pakerys 2015, 51 and Nau 2015, 114), and part of these are intransitive motion verbs; judinti is therefore an instance of a widely represented derivational pattern. But again, two things attract our attention. First, the verb form here cited as a parallel for nešdinkis is a reflexive causative, that is, we are dealing with the outcome of a twofold operation-transitivisation by means of a causative affix and intransitivisation of this causative by means of the reflexive marker. The question arises, therefore, what the difference could be between the primary intransitive verb and the secondary intransitive arising from reflexivisation of the causative. And, secondly, if 
there is indeed a semantic similarity between nešdinkis and judinkis, and both are in some way 'intensive', then perhaps it is precisely the notion of 'intensity' that provides an answer to the question just raised, that is, that of the difference between the primary intransitive and the intransitivised causative. We will explore this in the following sections.

\section{Transitivity pairs in Baltic}

In patterns of morphological marking opposing processes and their causation, languages may show a preference for transitivisation or intransitivisation, as noted for causative vs. anticausative pairs in Haspelmath (1993). In pairs like The firewood was burning : They were burning the firewood either the form for burn something may be derived with a causative marker from the intransitive burn, or the latter may be derived from its transitive counterpart by means of an intransitivising marker. Baltic has both devices, combining productive processes of intransitivisation by means of the reflexive marker and causativisation by means of the affixes - $(d)$ in- or - $(d)$ $y$-, as recently noted by Nau \& Pakerys (2016), who also pose the question which type of derivation is preferred for which types of lexical items. For the sake of completeness, let us add that Baltic has five strategies for opposing processes and their causation: (i) zero marking (the verb is labile), (ii) ablaut (with additional differences in conjugational class, cf. Arkadiev 2013 for a recent overview), (iii) intransitivisation with the aid of the reflexive marker, (iv) transitivisation with the aid of a causative affix, and (v) equipollent marking, combining (iii) and (iv). An overview is given in Table 1:

Table 1. Transitivity oppositions in Baltic

\begin{tabular}{|c|c|c|c|}
\hline & & intransitive & transitive \\
\hline $\mathrm{i}$ & zero (labile) & $d e g-t i$ 'burn (INTR)' & deg-ti 'burn (TR)' \\
\hline ii & ablaut & kil-ti 'rise' & $k e l-t i$ 'raise' \\
\hline iii & intransitivisation & $i \check{s}$-si-pil-ti 'spill (INTR)' & $i s ̌-p i l-t i$ 'spill (TR)' \\
\hline iv & transitivisation & $a u g-t i$ 'grow (INTR)' & aug-in- $t i$ 'grow (TR)' \\
\hline $\mathrm{v}$ & equipollent & $i s ̌-s i-g a s-t i$ 'get frightened' & $i s ̌ g q s-d i n-t i$ 'frighten' \\
\hline
\end{tabular}

In what follows we will focus on (iii) and (iv), as in (ii) no direction of derivation can be established (historically we are dealing here with a reanalysis of ablaut grades whose motivation was originally different, cf. 
Stang 1966, 331-333, 356), and the same applies to (v), where the marking is equipollent.

Transitivising and intransitivising derivation are not always alternative and mutually exclusive devices for creating transitivity pairs. In a situation where both devices coexist, there is a possibility of their being applied cumulatively, a verb stem being first transitivised by causative derivation and then intransitivised by means of a reflexive marker. Examples of this are not difficult to find in the modern Baltic languages, but they often involve a certain lexical specialisation of the causative derivative which opens the way for the formation of a new intransitive differing in meaning from the primary intransitive. An example would be Lithuanian šilti 'get warm' $\rightarrow$ šildyti 'warm (up)' $\rightarrow$ šildytis 'warm oneself'. Here the reflexivised causative differs in meaning from the primary intransitive: it can be used of an animate being warming itself at a fire, in the sun etc. In this case the lexical specialisation provides a raison d'être for the coexistence of a causative and a reflexive derivation based on the same verbal root:

(5) Lithuanian (Vytautas Bubnys, 1997, CCLL)

$\begin{array}{lllll}\text { linksmai } & \text { spraga } & \text { degančios } & \text { šakos } & \text { ir } \\ \text { merrily } & \text { crackle.PRS.3 burn.PPRA.NOM.PL.F } & \text { twig.NOM.PL } & \text { and } \\ \text { šyla } & & \text { suledijusios } & \text { rankos } & \\ \text { get.warm.PRS.3 } & \text { turn.into.ice.PPA.NOM.PL.F } & \text { hand.NOM.PL } & \end{array}$

'...burning twigs crackle merrily and your hands, numb from the cold, get warm'

(6) Lithuanian (Jaroslavas Melnikas, 2008, CCLL)

$\begin{array}{lllll}\text { Man } & \text { patinka, } & \text { kai } & \text { ugnis } & \text { šildo } \\ \text { 1SG.DAT } & \text { please.PRs.3 } & \text { when } & \text { fire.NOM.SG } & \text { warm.PRs.3 } \\ \text { kojas. } & & & & \end{array}$

foot.ACC.PL

'I like the fire warming my feet.'

(7) Lithuanian (Bronius Kmitas, 1994, CCLL)

$\begin{array}{lll}\text { prie } & \text { spanguoliu } \quad \text { kero } & \text { ant } \\ \text { next.to.NOM.SG } & \text { cranberry.GEN.PL bush.GEN.sG on } \\ \text { kelmo } & \text { saulèje šildo-si } & \\ \text { tree.stump.GEN.SG } & \text { sun.LOC warm.CAUS.PRS.3-REFL } \\ \text { kita } & \text { gyvaté. } & \\ \text { other.NOM.SG.F } & \text { snake.NOM.SG }\end{array}$

'Another snake is warming itself in the sun on a tree stump near a cranberry bush.' 
But not always is there a process of lexicalisation differentiating the original and the derived intransitive. If the two devices coexist, there is, in principle, a possibility that their mere availability will lead to an overkill and that we will find triads where the successive operation of the causative and the intransitivising derivation leads to the coexistence of primary intransitive and derived intransitive verbs without a clear functional differentiation. This could lead, in principle, to three types of development: (i) coexistence of original and derived intransitives without difference in meaning, (ii) elimination of either the original or the derived intransitive, and (iii) creation of a semantic differentiation. In fact, all three situations are represented, to a certain extent, in Baltic. We will first give an overview of these three types of situations by looking at the situation in Old Lithuanian and comparing it with the modern language.

\section{Reflexive causatives in the history of Baltic}

Type (ii), involving loss of the intransitivised causative, is observed in a group of verbs that is not of immediate interest to us here; they are derived, with the aid of a causative suffix, from adjectives. Such verbs are traditionally known as factitives. In Chyliński ${ }^{8}$ we find nusimažinti 'become smaller, be diminished', pasistiprinti 'become stronger', prasiplatinti 'expand' and others:

(8) Old Lithuanian (Chyl NT, Luke 12.33)

$\begin{array}{llcl}\text { patis } & \text { fau } & \text { padarÿkite }[. . .] & \text { skorba } \\ \text { self.NOM.PL.M } & \text { REFL.DAT make.IMP.2PL } & \text { treasure.ACC.SG } \\ \text { kuris } & \text { ne-nu-fi-mazyna } & \text { Dangose } \\ \text { REL.NOM.SG.M } & \text { NEG-PFX-REFL-small.cAUS.PRS.3 } & \text { Heaven.INE.PL } \\ \text { 'make yourself ... a treasure that does not diminish in Heaven' } & \\ \text { (Dutch: eenen schat die niet af en neemt inde hemelen) } & \\ \text { Old Lithuanian (Chyl OT, 1Sam 2.1) } & \text { and } \\ \text { nafrey } & \text { mano } & \text { pra-si-ptatyno } & \text { over } \\ \text { mouth[PL].NOM } & \text { my } & \text { PFX-REFL-broad.CAUs.PST.2 }\end{array}$

\footnotetext{
${ }^{8}$ Samuel Boguslaus Chyliński $(† 1666)$ was a Lithuanian Calvinist Bible translator who based himself mainly on the Dutch Statenvertaling, the Bible translation commissioned by the Estates General of the Netherlands. Chyliński's Old Testament was partly printed in London in 1660, while his New Testament is extant in the manuscript. His text is here chosen to represent Old Lithuanian because the narrative sections of the Bible contain a sufficient number of instances of the verbs relevant to our topic, including motion verbs.
} 
$\begin{array}{lc}\text { neprietelu } & \text { mano } \\ \text { enemy.GEN.PL } & \text { my } \\ \text { 'my mouth is enlarged over mine enemies' }\end{array}$

In modern Lithuanian these verbs have been ousted by primary intransitives in -éti of the type sumažèt $i$ 'diminish, become smaller', sustiprèti 'gain strength'. Such intransitives must already have existed in Old Lithuanian: Otrębski $(1965,367)$ cites imiklejęs 'inveterate' (Pol. zatwardziaty), the past active participle of a verbal derivative based on miklas 'hard', from Daukša's Postil, which implies the existence of an intransitive imikleti 'become hardened'. But they don't seem to have been highly frequent in Old Lithuanian, or at least they were much less frequent than the corresponding causative (factitive) derivation, so that the preferred strategy was to derive a factitive verb and then to intransitivise it by means of reflexivisation. The intransitives in -ett seem to have achieved a greater productivity relatively recently, and their expansion was no doubt a factor in the demise of verbs like nusimažinti 'wane, diminish', pasistiprinti 'grow stronger' etc. ${ }^{9}$ In Latvian, the reflexivised factitive verbs have remained in use: 'diminish' (INTR) is still samazināties (karstums samazinājās 'the heat diminished'), and 'increase, gain strength' is pastiprināties (sāpes pastiprinājās 'the pain increased'), while Lithuanian would have sumažejo and sustiprejo respectively. As said above, this group of verbs is not of interest to us here because a verb like Old Lithuanian nusimažinti 'wane, diminish' is not derived from an intransitive verb corresponding to modern Lithuanian sumažet $i$; the similarity of the Old Lithuanian situation to the other types of reflexive causatives discussed in the article consists only in that in Old Lithuanian we find a reflexive causative where from the point of view of the modern language we would expect a primary intransitive.

A development of type (i), involving the retention of an intransitivised causative alongside the primary intransitive, is represented by a group consisting of deverbal causatives with original intransitive counterparts, mostly also attested in the texts, the original intransitive and the intransitivised causative competing without any obvious difference in meaning. The examples below illustrate the primary intransitive (10), the derived causative (11), and the intransitivised causative (12):

\footnotetext{
${ }^{9}$ They may, however, survive in agentive meaning, as in pasistiprinti 'refresh oneself with food'. A reflexive susimažinti still exists, but it is transitive, and its reflexive marker points to a possessive relationship between object and agent, as in susimažinti alga 'cut one's (own) salary'.
} 
(10) Old Lithuanian (Chyl от, Gen. 6.12)

$\begin{array}{llllll}\begin{array}{l}\text { Regiejo } \\ \text { see.PST.3 } \\ \text { pagiedo. }\end{array} & \begin{array}{l}\text { tada } \\ \text { then }\end{array} & \begin{array}{l}\text { Diewas } \\ \text { God.NOM }\end{array} & \begin{array}{l}\text { ziame, } \\ \text { earth.ACC }\end{array} & \begin{array}{l}\text { ondey, } \\ \text { and }\end{array} \\ & & & & \end{array}$

be.corrupted.PsT.3

'And God looked upon the earth, and, behold, it was corrupt.'

(11) Old Lithuanian (Chyl ot, Gen. 6.12)

\begin{tabular}{lllll} 
wifokias & \multicolumn{2}{c}{ nes } & kunas & pagadyno \\
all.kind.NOM.SG.M & \multicolumn{2}{c}{ because } & body.NOM.SG & corrupt[TR].PST.3 \\
kiala & fawo & and & źiames & \\
way.ACC.SG & RPO & on & earth.GEN &
\end{tabular}

'for all flesh had corrupted his way upon the earth.'

(12) Old Lithuanian (Chyl ot, Gen. 6:11)

$\begin{array}{lll}\text { źiame } & \text { pa-fi-gadyno } & \text { po } \\ \text { earth.NOM } & \text { PFX-REFL-be.corrupted.cAUs.PST.3 } & \text { under } \\ \text { weydu } & \text { Diewo } & \\ \text { face.INS.SG } & \text { God.gEN } & \\ \text { 'the Earth was corrupt before God'; } & \end{array}$

Interestingly, both verbs still exist in modern Lithuanian, but pasigadinti is rare: CCLL has only 5 instances in the given sense as against 125 for pagesti. The reason for the retention of the reflexive causative pasigadinti alongside the original intransitive is unclear.

The third type of development, involving co-occurrence of an intransitivised causative and a primary intransitive but with a possible semantic difference, is observed in the case of a small group of motion verbs, and as these are immediately relevant to our topic, we will look at them in more detail. The base verbs for formally marked caused-motion verbs are verbs in - $\dot{e}$-, such as krutet $i^{10}$

(13) Old Lithuanian (Chyl oт, Gen. 9.3)

Wis tey kas kruta, kas ira all.N that what.NOM move.PRs.3 what.NOM be.PRS.3

${ }^{10}$ In Chyliński krut- seems to be the basic lexical root for 'moving', not jud- as in modern Lithuanian. The root jud- has metaphorical meanings such as 'become agitated, agitate' (as in Num. 14.1 sujudo tada wifas furynkimas, which renders Dutch doe verhief haer de geheele vergaderinge 'then the whole congregation arose'), in the causative form also 'provoke (to anger etc.)' (as in Deut. 31.29 kad pajudyntumite ghi ruftibefp darbu raku jufu 'to provoke him to anger through the work of your hands'). 
$\begin{array}{lllll}\text { giwu, } & \text { t'eft } & \text { jumus } & \text { and } & \text { pena. } \\ \text { alive.INS.SG } & \text { HORT.be.PRS.3 } & \text { 2PL.DAT } & \text { for } & \text { food.GEN.SG }\end{array}$

'Every moving thing that liveth shall be meat for you.'

This verb derives a causative with the productive causativising suffix -in-:

(14) Old Lithuanian (Chyl ot, Ex. 11.7)

$\begin{array}{lllll}\text { Bet } & \text { wifofe } & \text { waykofe } & \text { Izraelaus } & \\ \text { but } & \text { all.INE.PL.M } & \text { child.INE.PL } & \text { Israel.GEN } & \\ \text { ne-pakrutins } & \text { fzuo } & \text { lieźuwia } & \text { fawo. } \\ \text { NEG-PFX.move.CAUS.FUT.3 } & \text { dog.NOM.SG } & \text { tongue.GEN.SG } & \text { RPO }\end{array}$

'But amongst the children of Israel not a dog shall move his tongue.'

This causative, in its turn, underlies a derived intransitive with a reflexive marker. In the following examples the perfective ${ }^{11}$ forms with the prefix $p a$ - are used, a fact which is not without importance, as we will see below:

(15) Old Lithuanian (Chyl NT, Rev. 6.14)

katney ir iwos

mountain.NOM.PL and island.NOM.PL

pa-fi-krutyno isz fawo wietu

PFX-RE FL-move.CAUS.PST. 3 out.of RPO place.GEN.PL

'And every mountain and island were moved out of their places.'

(16) Old Lithuanian (Chyl oт, 2Sam 22.8)

[Trefzejo tada ir drebejo źiame,]

fundamentey dagaus pa-fi-krutyno...

foundation.Nom.PL heaven.gen.sg PFX-REFL-move.cAus.PST.3

'[Then the earth shook and trembled;] the foundations of heaven moved.'

Another verb of motion showing the same pattern is viskèti 'swing (INTR)' $\rightarrow$ viskinti 'swing (TR)' $\rightarrow$ viskintis, usually pa-si-viskinti 'begin a swinging motion':

${ }^{11}$ As one of the reviewers points out, the existence of verbal aspect in Lithuanian, and in Baltic in general, is not generally recognised. My view (expounded in Holvoet 2014) is that Baltic, like Slavonic, has grammaticalised lexical aspect classes, the difference being that the degree of grammaticalisation is lesser in Baltic than in Slavonic. For a slightly different view, positing a more pronounced contrast between Baltic and Slavonic, see Arkadiev (2011). 
(17) Old Lithuanian (Chyl ot, Lev. 7.30)

$\begin{array}{lllc}\text { wifkint } & j q & \text { and } & \text { wifkamos }^{{ }^{12}} \\ \text { swing.CAUS.INF } & \text { 3.ACC.SG.F } & \text { for } & \text { swing.PPRP.GEN.SG.F } \\ \text { afieros } & \text { po } & \text { weydu } & \text { Wieszpaties. } \\ \text { offering.GEN.SG } & \text { under } & \text { face.INS.SG } & \text { Lord.GEN.SG }\end{array}$

(18) Old Lithuanian (Chyl NT, Acts 16.26)

$\begin{array}{llll}\text { teyp jog } & \text { pamatey } & \text { kalines } \\ \text { so that } & \text { foundation.NOM.PL } & \text { prison.GEN.SG } \\ \text { pa-fi-wifkino } & & \\ \text { PFX-RE FL-swing.CAUS.PST.3 } & \end{array}$

'so that the foundations of the prison were shaken'

The existence of reflexivised causatives as illustrated in (16) may be observed not only in Old Lithuanian but also in Old Latvian. The Old Latvian counterparts of krutèti : krutinti : krutintis are kustēt(ies) : kustināt : kustināties. Kustēt and kustēties do not seem to differ in meaning; the reflexive could be characterised as a 'motion middle' as it is not opposed to a transitive kustett. ${ }^{13}$ The non-reflexive and reflexive forms of the same meaning are shown in (19) and (20):

(19) Old Latvian (Glück oт, Gen. 9.3)

\begin{tabular}{|c|c|c|c|c|c|}
\hline $\begin{array}{l}\text { Wifs } \\
\text { all.NOM. }\end{array}$ & & $\begin{array}{l}\text { kas } \\
\text { that.NOM }\end{array}$ & $\begin{array}{l}\text { kuft } \\
\text { move.PRs.3 }\end{array}$ & $\begin{array}{l}\text { un } \\
\text { and }\end{array}$ & $\begin{array}{l}d f i h w s \\
\text { alive.NOM.SG.M }\end{array}$ \\
\hline irr & laid & $i r r$ & jums & par & Barribu. \\
\hline be.PRS.3 & HORT & be.PRS.3 & 2PL.DAT & for & food.Acc.sG \\
\hline
\end{tabular}

(20) Old Latvian (Glück ot, Gen. 7.22)

[Tad islaide to Dfihwibu]

$\begin{array}{lllll}\text { wiffa } & \text { Meefal } & \text { kas } & \text { wirs } & \text { Semmes } \\ \text { all.NOM.SG.F } & \text { flesh.NOM.sG } & \text { that } & \text { on } & \text { earth.GEN }\end{array}$

${ }^{12}$ Though referred to as as present passive participle, the form viskamas used here as well as in all other references to this type of offerings is, when used adnominally, actually neutral with respect to voice; here it is derived from the intransitive visketi 'swing (INTR)', as modern Lithuanian judamas 'mobile' is from the intransitive judeti 'move'. More examples in Ambrazas (1979, 47).

${ }^{13}$ Interestingly, we find ne weens funs fawu Mehli kuftehs 'not a dog shall move his tongue' in Ex. 11.7 rather than the expected kuftinahs. The suffix -ē- also derives causatives and alternates in this function with -inā- (cf. dziedēt alongside dziedināt 'heal'), but this transitive kustēt would be isolated and may simply be a mistake. 


\section{kuftah-s}

\section{mOve.PRS.3-REFL}

'And all flesh [died] that moved upon the earth.'

The following examples illustrate the causative kustināt and its intransitivised reflexive form kustināties:

(21) Old Latvian (Glück's OT, 2 Kings 23.18)

[Lai winffch gull,]

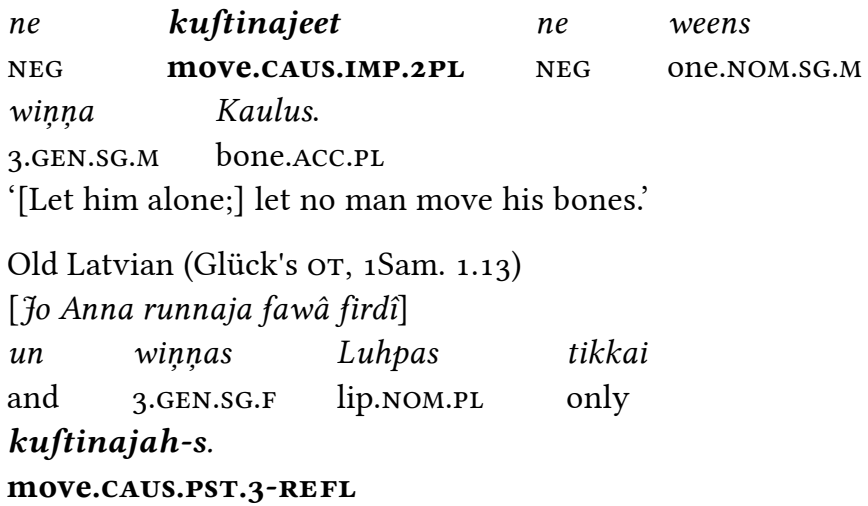

'[Now Hannah, she spake in her heart] and only her lips moved.'

Here we will concentrate on Lithuanian. What were the principles of use of the original intransitives and the intransitivised causatives in Old Lithuanian? Clearly no process of lexicalisation as illustrated above for šildyti was at work here. The subject of the intransitivised causative was not necessarily higher in agentivity than that of the original intransitive, as one might have expected in view of the causative character of the formation. The subject could be inanimate, as shown in (15) and (16). This does not exclude the relevance of agentivity, but shows it was not the only factor.

The interpretation of Old Lithuanian examples is always subjective, but the evidence of Chylinski's Bible translation seems to confirm the idea of an intensivity effect conveyed by the reflexive causatives. The primary intransitive kruteti is attested 8 times in Chylinski's Bible; in addition to the examples similar to (6), one example refers to the spirit of God:

(23) Old Lithuanian (Chyl oт, Gen. 1.2)

$\begin{array}{llll}\text { ó } & \text { Dwafia } & \text { Diewo } & \text { krutejo } \\ \text { and } & \text { Spirit.Nom.Sg } & \text { God.gen } & \text { move.PST.3 } \\ \text { and } & \text { wazdeniu } & & \\ \text { on } & \text { water.GEN.PL } & & \end{array}$

'And the Spirit of God moved upon the face of the waters.' 
The remaining 6 instances refer to living creatures moving upon the earth or in the water (Gen. 7.21, Gen. 8.19, Gen. 9.2, Gen. 9.3, twice in Lev. 11.46), so that the interpretation is durative or iterative, e.g., (24) (the counterpart of Latvian ex. (20)):

(24) Old Lithuanian (Chyl oт, Gen. 7.21)

[Ir atadawe dwafia,]

$\begin{array}{llll}\text { wifokias } \quad \text { kunas } & \begin{array}{l}\text { kurfey } \\ \text { that.NOM.SG.M }\end{array} & \begin{array}{l}\text { krutejo } \\ \text { move.PST.3 }\end{array} \\ \text { all.NOM.SG.M body.NOM.SG } & & \\ \text { and } & \text { ziames } & & \\ \text { on } & \text { earth.GEN } & & \end{array}$

'And all flesh [died] that moved upon the earth.'

In all these cases the meaning is durative and time-stable. The reflexive causative is represented by its perfective variety pasikrutinti, which refers to more forceful and dynamic processes such as natural elements being set in motion by Divine agency, illustrated by (8) and (9) above, and also by pasiviskino in (18). One instance has a human subject, referring to Mordechai's failing to rise before Haman:

(25) Old Lithuanian (Chyl oт, Esther 5.9)

$\begin{array}{llll}\text { jog } & \text { ne-fi-kiete } & \text { ney } & \text { pa-fi-krutyno } \\ \text { that } & \text { NEG-REFL-raise.PST.3 } & \text { nor } & \text { PFX-REFL-move.cAUS.PST.3 } \\ \text { priefz ghi, } & & \\ \text { before } & \text { 3.ACC.SG.M } \\ \text { 'that he stood not up, nor moved for him' }\end{array}$

The meaning is, in all these instances, more punctual and dynamic than in the examples with kruteti, the animacy of the subject being apparently not decisive. ${ }^{14}$

\section{Modern Lithuanian}

In modern Lithuanian, verbs belonging to our group comprise krutintis 'budge, move', judintis 'move' and we could add skubintis 'haste', although the last is not a pure motion verb as it also means 'do something quickly'. Viskinti and viskintis have fallen out of use. Among these, judintis is particularly

\footnotetext{
${ }^{14}$ We make no attempt to establish possible semantic differences between the reflexive causatives and the underlying original intransitives in Old Latvian, nor will we do this for Modern Latvian. It is possible that a difference exists, but our aim was to account for the Lithuanian facts.
} 
frequent in the imperative: 49 out of 83 occurrences in CCLL are imperatives. For the perfective pasijudinti only 2 instances out of 105 are imperatives, but this is a matter of aspectual usage. Insistent exhortations to immediate action, with the result being defocused, are usually imperfective (this has been noted for Russian, cf. Rassudova 1968, 103-105, and it also holds for other Slavonic languages as well as for Baltic ${ }^{15}$ ); the low frequency of the perfective imperative $i s ̌$-si-nešdink therefore reflects the aspectual features of the imperatival construction in which the verbs under discussion typically occur. ${ }^{16}$ Here we give examples with the imperfective krutintis and skubintis:

(26) Lithuanian (Valdas Bartas, 2006, CCLL)

$\begin{array}{lll}\text { Krutinki-s, } & \text { Tadai, laikas } \\ \text { move.CAUS.IMP.2SG-REFL } & \text { PN.VOC time.NOM.SG } \\ \text { bega, - } & \text { paragino } & \text { Tamošiūnas. } \\ \text { run.PRS.3 } & \text { urge.PST.3 } & \text { PN.NOM }\end{array}$

'Get on with it, Tadas, the clock is ticking-Tamošiūnas urged him on.'

(27) Lithuanian (Juozas Aputis, 1996, CCLL)

[Sakiau, Rafaeli, kad bus... Oi, gera vietukè!]

Skubinki-s, Rafaeli, skubinki-s

hurry.CAUS.IMP.2SG-REFL PN.VOC hurry.IMP.2SG-REFL

i traukini.

into train.ACC.SG

'[I told you there would be [free seats]... O, what a nice little place!]

Hurry up, Raphael, get onto the train!'

What seems to be characteristic of the reflexive causatives is that they are dynamic and, even in their imperfective form and in non-imperatival uses, refer to the initial stage of a motion event. This can be seen in (28), which has a historical present (the equivalent in the past tense would be perfective: pasijudino).

${ }^{15}$ As the Baltic aspect system, like that of Slavonic (see fn. 9), rests on the grammaticalisation of oppositions in lexical aspect expressed in different verbal stems, both Slavonic and Baltic can oppose perfective and imperfective imperatives, while in languages where aspect is more closely bound up with tense, like Romance, this is impossible.

${ }^{16}$ The clear predominance of the imperfective imperative is also noted for nešdintis: CCLL contains 161 instances of the imperfective nešdinkis (nešdinkimès, nešdinkitès) and only 5 for išsinešdink (išsinešdinkime, išsinešdinkite). This use of the imperfective imperative is also reflected in the use of veskite lauk rather than išveskite in example (1). The Slavonic counterparts of such imperatives of motion verbs are mainly imperfective, cf. Russian ubirajsja 'off with you', Polish wynoś się 'get out of here' and the like. 
(28) Modern Lithuanian (Dalia Grinkevičiūtè, 1997, CCLL)

$\begin{array}{lllll}\text { Vèl } & \text { sugrūda } & i & \text { vagonus, } & \text { užrakina. } \\ \text { again } & \text { pack.together.PRs.3 } & \text { into } & \text { carriage.ACC.PL } & \text { lock.PRS.3 }\end{array}$

Judinamé-s.

move.CAUS.PRS.3-REFL

'They pack [us] together into the carriages again and lock them.

We jerk into motion.'

(29) Modern Lithuanian (Dalia Grinkevičiūtè, 1997, CCLL)

Akimirka, ir rogès judina-si-

moment.NOM.sG and sleigh.NOM.PL move.CAUS.PRS.3-REFL

[važiuojam su visu vežimu prie barako.]

'One moment and the sleigh slides into motion - [We are heading

with cart and all towards the barrack].'

Other present-tense uses are hortative; they could be replaced with the imperative and also refer to inceptive motion:

(30) Lithuanian (Glen Cook, 2003, CCLL)
Nagi, judinamé-s.
Kuriuo
keliu?
PTC move.CAUS.PRS.1PL-REFL
which.INS.SG.M way.INS.SG
'OK, off we go. Which road [shall we take]?'

In the infinitive, judintis is used in the CCLL contexts with desiderative verbs like nenorèti 'have no wish to', neketinti 'have no intention to', modals like reikia 'it is necessary', speech act verbs like liepti 'order' and raginti 'urge', as well as with laikas and metas 'it is time'. In all these cases conscious agency conditioned either by the agent's volition or an external stimulus is referred to, which justifies the choice of the reflexive causative verbs referring to inceptive motion requiring some effort:

(31) Lithuanian (Vytautas Katilius, 1996, CCLL)

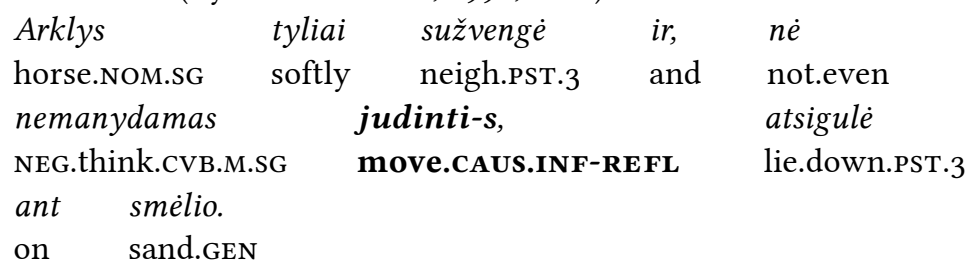

'The horse neighed softly and, without as much as considering to budge, lay down in the sand.'

The following pair of examples, with pakruteti and pasikrutinti, oppose externally observed motion to a motion act explicitly characterised as volitional and energetic: 
(32) Modern Lithuanian (Herbjorg Wassmo, tr. by Eglè Išganaitytė-

Paulauskienè, 2000, CCLL)

[fi atsinešè ryšulèli prie stalo ir įdejjo man ị rankas.]

fis pakrutejo. Šiluma nuo jo

3.NOM.SG.M PFX.move.PST.3 warmth.NOM from 3.GEN.SG.M

pasklido rankomis iki pat gerkles.

spread.PST.3 arm.INS.PL up.to very throat.GEN.SG

'[She brought the bundle over to the table and put it into my hands.]

It moved. Warmth spread from it through my arms up to my throat.'

(33) Modern Lithuanian (Romualdas Granauskas, 2006, CCLL)

[O Milda Marija narsiai atžygiavo žvyrkeliu, pasižvalgè iejusi ir klestelejo

i pati pirmaji suola priešais mokytojos stala,]

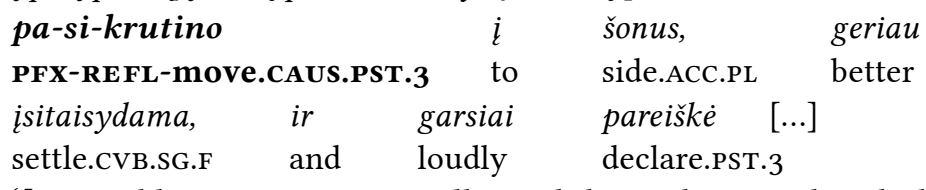

'[But Milda Marija energetically trod down the gravel path, looked about on entering, threw herself into the very first bench right across the teacher's table,] made a few sideways thrusts to install herself more comfortably, and declared loudly [...]'

On the whole, then, the reflexive causatives judintis and krutintis seem to be volitional, inceptive and/or energetic. As noted above, in Chylinski the reflexive causative is attested mainly with the perfectivising prefix pa-, as in (15) and (16); this is also consonant with an inceptive and dynamic value. These features predispose the verbs in question for use with animate subjects. This is not a general rule, and (just as in the case of Old Lithuanian above), we find inanimate subjects, as in (29). But these also indirectly reflect human agency, and it would, for example, be impossible to use judintis for the natural motion of a physical object:
(34) Žemé
juda
(*judina-si)
Earth.NOM.sG
move.PRS.3
(move.CAUS.PRS.3-REFL)
apie
Saule
around
Sun.ACC.SG
[ne apskritimu, o orbita, panašia i ištempta apskritima.]
'The Earth moves around the Sun [not circularly, but along an orbit resembling an elongated circle. $]^{17}$

\footnotetext{
${ }^{17} \mathrm{http}: / /$ gamta5-6.mkp.emokykla.lt/lt/mo/zinynas/kodel_keiciasi_metu_laikai (accessed 10-07-2020)
} 
The unacceptability of (34) with the reflexive causative verb shows that all the factors that could induce the use of such a form are absent here: there is no human agency, no visible external coercion, no energetic agency aiming at overcoming inertia and setting an object in motion. The factors mentioned here explain, on the other hand, why these verbs are frequently used in the imperative or when referring to directive speech acts. These factors can all occur in conjunction, but a subset of them can also be sufficient to motivate the use of the reflexive causative.

\section{The case of nešdintis again}

Of course there is an element of subjectivity in the interpretation of such examples from texts. It is also not very revealing to say that the subject of a causative is higher in agentivity that than of the corresponding intransitive, also when this causative is reflexivised. A more telling piece of evidence is that the verbs under discussion here seem to have attracted one more non-causative verb with causative morphology, viz. nešdintis 'take oneself off'. It is relatively frequently used in the imperative (161 instances out of 408 in CCLL). Apart from imperatives proper, indicative uses of nešdintis occur with the hortative marker $\operatorname{teg} u(l)$ and are directive in function:

(35) Lithuanian (Leonardas Gutauskas, 2008, CCLL)

$\begin{array}{lll}\text { tegu } & \text { panele } & \text { mokytoja } \\ \text { HORT } & \text { Miss.NOM.SG teacher[F].NOM.SG } \\ i \check{s} & \text { kur } & \text { atejus } \\ \text { from } & \text { where } & \text { come.PPA.NOM.SG.F }\end{array}$

nešdina-si,

carry.CAUS.PRS.3-REFL

'Let Miss teacher get herself back where she came from.'

Non-directive uses also refer to motion enforced by external circumstances:

(36) Lithuanian (Karys, 1995, CCLL)

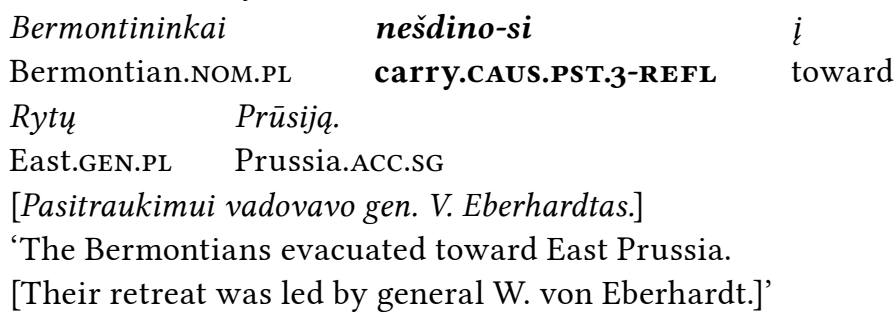

The difference between the derivational histories of nešdintis and the type krutintis was already mentioned above: the derivational base of nešdinti is 
transitive, and the causative marker has intensifying rather than causative function. The properly causative function of nešdinti is attested in Old Lithuanian:

(37) Old Lithuanian (Chyl oт, Gen. 37.32)

[Ir nusiunte anq jupq tutu-forbu,]

ir $\boldsymbol{n u}$-néz-dyno ja tewop

and PFX-bring-caus.PsT.3 3.ACC.SG.F father.ALl.SG

fawo.

RPO

'[And they sent the coat of many colours], and had it brought to their father.' Dutch: Ende sy sonden den veelverwigen rock, end deden hem tot haren vader brengen.

And there was a corresponding reflexive use 'have oneself carried about', attested in Sirvydas' Polish-Latin-Lithuanian dictionary:

(38) Sirvydas, Dictionarium trium linguarum 1642, 97 (Pakalka, ed., 1979, 195) [Káretá, lektyká. Lectica, vehiculum penfile.]

towa, patałas kuriami fwetimi

bed.NOM.SG litter.NOM.SG REL.INE.SG.M foreign.NOM.PL.M

nefzdina-fi

carry.CAUS.PRS.3-REFL

'[Lectica, vehiculum pensile.] Bed, litter in which foreigners have themselves carried about.'

As shown by examples (2) and (3), neštis could once have the meaning 'take oneself off, escape', and in this meaning it was probably replaced by nešdintis as a means of rendering an (exhortation to) energetic motion after the model of judintis, krutintis etc. That is to say, we need not assume a semantic development from a causative nešdintis to an intensive nešdintis. Rather, the evidence of neškis 'get away, take yourself off' suggests that nešdintis replaced neštis on the analogy of judintis, krutintis, and the existence of a causative nešdintis was not a precondition for this. The intransitive neštis is relatively rare, and it has none of the meanings associated with nešdintis: it simply means quick and uniform motion in one direction (cf. Russian nestis'):

(39) Lithuanian (Jonas Avyžius, LKž)

$\begin{array}{lll}\text { Ilgakojis } & \text { sartis } & \text { nešé-si } \\ \text { long.legged.NOM.SG.M } & \text { bay.horse.NOM.SG } & \text { carry.PST.3-REFL }\end{array}$


kaip vejas,

like wind.NOM

[lenkdamas iš bažnyčios grižtančius valstiečius.]

'The long-legged bay horse dashed forward like the wind, [overtaking the peasants who were driving back from church].'

The specific meaning of neštis in neškis 'take oneself off, leave a place under external compulsion' as illustrated in (2) and (3) might have arisen in the imperative, where it underwent the influence of reflexive causative imperatives like judinkis, and assumed their causative marking. We cannot corroborate this hypothesis with detailed evidence, at least until a historical corpus is available, but even if this happens it might be problematic to pinpoint a process that presumably occurred in the spoken language. Examples (2) and (3) with neškis instead of the later nešdinkis are from the early zoth century, but we also find attestations of nešdintis in the present-day meaning slightly predating examples (2) and (3):

(40) Lithuanian (Lietuva, 11-10-1901)

$\begin{array}{llc}\text { Koks } & \text { zokonas } & \text { neiszsidirbo } \\ \text { which.NOM.SG.M } & \text { order.NOM.SG } & \text { NEG.acquire.PST.3 } \\ \text { valdžiu } & \text { daleidimo, } & \text { turi } \\ \text { authority.GEN.PL } & \text { permission.GEN.SG } & \text { have.to.PRs.3 } \\ \text { neszdintie-si } & \text { laukan. }{ }^{18} & \\ \text { carry.CAUS.INF-REFL } & \text { out } & \end{array}$

'Those religious orders that have not been granted permission by the authorities [to stay] must get out [of the country.]'

This means that nešdintis was probably already in use at least in the late 19th century. A historical corpus covering the relevant period would yield a more accurate picture, but an exact chronology is not a necessary condition for establishing the derivational mechanisms at work.

\section{In conclusion}

Intensive functions of causative morphology are typologically well attested. Lithuanian has a small number of causative formations showing this semantic specialisation. What is specific about the Lithuanian in-

\footnotetext{
${ }^{18}$ http://www.spauda.org/lietuva/archive/1901/1901-10-11-LIETUVA.pdf (accessed 10-07-2020)
} 
stances is that the intensive function manifests itself only in the reflexive, intransitivised forms of a small group of verbs with causative markers. This was originally a consequence of the co-occurrence of causative (transitivising) and reflexive (detransitivising) markers as devices for deriving transitivity pairs. Transitivised verbs (with causative markers) could be in their turn detransitivised by reflexivisation, and a semantic differentiation arose between the primary intransitive and the derived (causative-reflexive) intransitive. This is illustrated by the derivational chain judeti 'move' $\rightarrow$ judinti 'set in motion' $\rightarrow$ judinti-s 'set oneself in motion'. The case of nešdintis is different in that it does not result from a derivational chain nešti 'carry' $\rightarrow$ nešdinti 'have something carried' $\rightarrow$ nešdinti-s 'take oneself off'. Indeed, nešdintis is, in its present-day meaning, not derived from nešdinti but from nešti-s, and the function of the causative derivation is here exclusively intensive. This instance of causative derivation with intensive function could arise only after the intensive meaning had established itself in judintis and the like. The cause for the rise of intensive meaning was apparently structural: the co-occurrence of reflexivisation and causativisation as devices for building transitivity pairs led to a semantic differentiation between primary and derived intransitive, which took the shape of intensive meaning. As a reviewer of this article points out, this could be characterised as an instance of exaptation as defined by Lass (1990). In view of the frequent use of the intensive reflexive causatives under discussion in the imperative and other hortative forms and contextsi, it deserves to be considered whether they do not centre around an imperatival construction.

\section{ABBreviations}

ACC - accusative, ALL - allative, cAUs - causative, CVB - converb, DAT dative, $\mathrm{F}$ - feminine, FUT - future, GEN - genitive, HORT - hortative, IMP imperative, INE - inessive, INF - infinitive, INS - instrumental, INTR intransitive, LOC - locative, $\mathrm{M}-$ masculine, $\mathrm{N}-$ neuter, NEG - negation, NOM - nominative, PFX - prefix, PL - plural, PN - personal name, PPA - past participle active, PPRA - present participle active, PPRP — present participle passive, PRs - present, PST - past, PTC - particle, REFL - reflexive, REL relative pronoun, $\mathrm{RPO}$ - reflexive possessive, $\mathrm{SG}$ - singular, $\mathrm{TR}$ - transitive, voc - vocative 


\section{SOURCES}

CCLL - Corpus of the Contemporary Lithuanian Language at http://tekstynas. vdu.lt

Chyl NT - Samuel Boguslaus Chyliński’s New Testament at http://www.chylinskibible.flf.vu.lt

Chyl oт - Vetus Testamentum Samueli Boguslai Chylinski Lithuanicâ Linguâ Donatum, ed. Gina Kavaliūnaitè, Vilnius: Lietuvių kalbos institutas, 2007.

Glück NT, OT - Glück’s Latvian Bible at http://senie.korpuss.lv

LKž - Lietuviu kalbos žodynas at http://www.lkz.lt

Pakalka, Kazys, ed., 1979. Pirmasis lietuviu kalbos žodynas: Dictionarium trium linguarum. Vilnius: Lietuvos TSR Mokslų akademijos Centrinė biblioteka.

\section{REFERENCES}

Aikhenvald, Alexandra Y. 2018. Causatives which do not cause: Nonvalency-increasing effects of a valency-increasing derivation. In: Alexandra Y. Aikhenvald \& R. M. W. Dixon, Language at Large. Essays on Syntax and Semantics. Leiden: Brill, 86-142.

Ambrazas, Vytautas. 1979. Lietuviu kalbos dalyviu istorine sintaksé [Historical Syntax of the Lithuanian Participles]. Vilnius: Mokslas.

Arkadiev, Peter. 2011. Aspect and actionality in Lithuanian on a typological background. In: Daniel Petit, Claire Le Feuvre \& Henri Menantaud, eds., Langues baltiques, langues slaves. Paris: Editions CNRs, 61-92.

Arkadiev, Peter. 2013. From transitivity to aspect: The causative-inchoative alternation and its extensions in Lithuanian. Baltic Linguistics 4, 39-77.

Arkadiev, Peter \& Jurgis Pakerys. 2015. Lithuanian morphological causatives. A corpus-based study. In: Axel Holvoet \& Nicole Nau, eds., Voice and Argument Structure in Baltic, Amsterdam-Philadelphia: John Benjamins, 39-97.

Dixon, R. M. W. 2000. A typology of causatives: form, syntax and meaning. In: R. M. W. Dixon \& Alexandra Y. Aikhenvald, eds., Changing Valency. Case Studies in Transitivity, Cambridge: Cambridge University Press, 30-83.

Haspelmath, Martin. 1993. More on the typology of inchoative/causative verb alternations. In: Bernhard Comrie \& Maria Polinsky, eds., Causatives and Transitivity, Amsterdam-Philadelphia: John Benjamins, 87-120.

Holvoet, Axel. 2014. Phasal and proximative complementation: Lithuanian baigti. Baltic Linguistics 5, 81-122. 
Holvoet, Axel. 2015. Extended uses of morphological causatives in Latvian. In: Axel Holvoet \& Nicole Nau, eds., Voice and Argument Structure in Baltic, Amsterdam-Philadelphia: John Benjamins, 147-177.

Holvoet, Axel. 2020. The Middle Voice in Baltic. Amsterdam-Philadelphia: John Benjamins.

Kittilä, SEPpo. 2009. Causative morphemes as non-valency-increasing devices. Folia Linguistica 43.1, 67-94.

Kulikov, LeONid I. 1993. The "second causative": A typological sketch. In: Bernard Comrie \& Maria Polinsky, eds., Causatives and Transitivity. Amsterdam-Philadelphia: John Benjamins, 121-145.

Kulikov, LeOnid I. 2001. Causatives. In: Martin Haspelmath et al., Language Typology and Language Universals. An International Handbook, Vol. 2. Berlin etc.: Mouton de Gruyter, 886-898.

LASS, Roger. 1990. How to do things with junk: Exaptation in language evolution. Journal of Linguistics 26, 79-102.

NAU, NicOle. 2015. Morphological causatives in contemporary Latvian. In: Axel Holvoet \& Nicole Nau, eds., Voice and Argument Structure in Baltic. Amsterdam-Philadelphia: John Benjamins, 99-145.

Nau, Nicole \& Jurgis Pakerys. 2016. Transitivity pairs in Baltic: Between Finnic and Slavic. Lingua Posnaniensis 63.2, 83-126.

Nedjalkov, Vladimir P. \& Georgij G. Sil'nickij. 1969. Tipologija morfologičeskogo i leksičeskogo kauzativov [The typology of the morphological and lexical causative]. In: Aleksandr Xolodovič, ed., Tipologija kauzativnyx konstrukcij. Morfologičeskij kauzativ [Typology of Causative Constructions. The Morphological Causative]. Leningrad: Nauka, 20-50.

OtrębSKi, Jan. 1965. Gramatyka języka litewskiego. Vol. ii. Nauka o budowie wyrazów [Lithuanian Grammar: Word Formation]. Warszawa: Państwowe Wydawnictwo Naukowe.

Rassudova, O. P. 1968. Upotreblenie vidov glagola v russkom jazyke [The Use of the Verbal Aspects in Russian]. Moscow: Izdatel'stvo Moskovskogo universiteta.

Stang, Christian S. 1966. Vergleichende Grammatik der baltischen Sprachen. Oslo-Bergen-Tromsö: Universitetsforlaget.

\author{
Axel Holvoet \\ Vilnius University \\ Institute for the Languages and Cultures of the Baltic \\ Universiteto 5 \\ LT-01131 \\ axel.holvoet@flf.vu.lt
}

